\title{
ДИСЦИПЛІНАРНА ВІДПОВІДАЛЬНІСТЬ ДЕРЖАВНИХ СЛУЖБОВЦІВ ЗА НЕВИКОНАННЯ ВИМОГ ЩОДО ПОЛІТИЧНОЇ НЕУПЕРЕДЖЕНОСТІ
}

Андрєєва А. П.

Cтаття складається із двох взаємопов'язаних частин. У першій частині розглядається склад дисциплінарного проступку у вигляді невиконання вимог щодо політичної неупередженості державним службовцем (пункт 8 частини 2 cтатті 65 Закону України «Про державну службу» від 10 грудня 2015 року). Підкреслено, що встановлення всіх обов'язкових елементів складу дисциплінарного проступку дає змогу застосувати суб'єктом призначення або керівником державної служби до державного службовия таке дисциплінарне стягнення, як повідомлення про неповну службову відповідність. Розкриті елементи складу дисциплінарного проступку «невиконання вимог щодо політичної неупередженості державного службовця»: 1) безпосередній об'єкт як обов'язок додержуватись принципу політичної неупередженості; 2) обов'язкові та факультативні ознаки об'єктивної сторони, унаслідок чого було зроблено висновок про формальний склад цього проступку; 3) загальний та спеціальний суб'єкти проступку; 4) обов'язкова ознака суб'єктивної сторони - вина, характеристика їі форм (умисел, необережність). Зроблено висновок про факультативний (необов'язковий длявстановлення під час дисциплінарного провадження) характер мотиву і мети дисциплінарного проступку.

у другій частині статті аналізується доцільність посилення дисциплінарного стягнення за наведений проступок. Зазначається, що від цього безпосередньо залежатиме ефективність дисциплінарної відповідальності, недопущення вчинення державним службовцем повторного проступку. Описується питання сумірності суворості попередження про неповну службову відповідність як дисциплінарного стягнення стосовно рівня шкідливості невиконання вимог щодо політичної неупередженості. Зверта$\epsilon$ єься увага на досвід Литовської Республіки щодо застосування санкцій за діяльність, несумісну із службою. Запропоновано передбачити в Законі України «Про державну службу» від 10 грудня 2015 року звільнення з посади державної служби за повторне протягом року вчинення невиконання вимог щодо політичної неупередженості.

Ключові слова: політична неупередженість, політична активність, державні службовці, дисциплінарний проступок, дисциплінарне стягнення.
Andrieieva A. P. Disciplinary liability of civil servants for failure to fulfill requirements in terms of political impartiality

Ukrainian legislation is about to change a soviet-oriented model of administration that provided the unity of political and governmental authorities. In that case, state servants made political party's goals come to fruition instead of trying to stay unbiased and help people realize their rights efficiently. New vision of civil service characterizes it as public, professional and politically neutral activity. In order to make this statement practically implemented instead of only announced as an aim, Law of Ukraine on Civil Service from 10.12.2015 provides a disciplinary sanction for violation of political impartiality requirements. Disciplinary and other types of liabilities might correct state servants' behavior in accordance with politically unbiased treatment to everyone at the service, prevent new offences, influence positively on their behavior onward and stimulate their more considered attitude to service and responsibilities.

The relevance of this topic is huge and a lot of lawyers had already devoted their theses, articles or even monographs to disciplinary liability of civil servants. But the vast majority of such papers are rather theoretical than practical and don't describe certain disciplinary wrongdoings. Moreover, a lot of them were written during the existence of the former Law of Ukraine on Civil Service from 16.12.1993. As a result, a modern administrative science requires new researches on disciplinary wrongdoings. Some of them should be aimed to evaluate the value of political impartiality for civil service. And also it's highly important to compare such value with objective and fair strictness of sanction of the violation of failure to fulfill requirements in terms of political impartiality.

The article includes two interrelated parts. The first part is devoted to the composition of failure to fulfill requirements in terms of political impartiality (Article 65 of Law of Ukraine on Civil Service from 10.12.2015). It is emphasized that clarifying of all parts of disciplinary offence may help an appointing entity and a head of civil service in a government agency to apply to the civil servant warning of incomplete conformance to the service. Parts of the composition of failure to fulfill requirements in 
terms of political impartiality are explained: 1) direct object as an obligation to adhere to the principle of political impartiality; 2) mandatory and optional features of direct object which show the formal composition of the offence; 3) non-special (general) and special subjects of offence; 4) mandatory feature of subjective part - guilty, characteristics of its forms (intent and recklessness). The conclusion is made that motive and purpose of the offence are not demanded to be clarified during the disciplinary procedure.

The second part of the article provides the analysis of making stricter the disciplinary sanction of the offence. It is mentioned that it impacts the efficiency of disciplinary liabilityandprotectsthestateservantfrom thereoccurrence of offence. Harm of the disciplinary offence and strictness of the sanction are compared. The author describes the way of applying sanctions for the unrelated activities to the goals of the state service in accordance with Lithuanian experience. It is proposed to provide in Law of Ukraine on Civil Service from 10.12.2015 dismissal from civil service as a sanction for the reoccurrence of failure to fulfill requirements in terms of political impartiality during the year.

To sum up, political impartiality makes Ukrainian civil service closer to European requirements. It's vital to find legal mechanisms which will help lawyers to guarantee political impartiality as a guideline for our country. Politicians mustn't take advantage of civil servants as well as civil servants mustn't take advantage of their positions in order to demonstrate political attitudes or help political party's goals to be realized. This rule will help to build a credible, stable, efficient and unbiased civil service in Ukraine.

Key words: political impartiality, political activity, civil servants, disciplinary wrongdoing, disciplinary proceeding.

Постановка проблеми та іï актуальність. Поступовий відхід від радянської моделі врядування, яка передбачала злиття влади партійної та державної, означає перетворення державної служби в Україні на політично неупереджений інститут. Такий інститут професійно та неупереджено забезпечуватиме реалізацію державної політики, а не політики окремої партії або партій. Складовою частиною законодавчого підґрунтя цього процесу $\epsilon$ положення Закону України «Про державну службу» від 10 грудня 2015 р. (далі Закон), за яким державна служба характеризується як політично неупереджена діяльність, а до державних службовців окремою статтею висувається низка вимог стосовно їхньої політично неупередженої поведінки. 3 метою забезпечення дотримання цих положень законодавець закріпив невиконання вимог щодо політичної неупередженості як різновид дисциплінарних проступків держав- них службовців. Дисциплінарна й інші види відповідальності мали 6 справляти виправний вплив на державних службовців, запобігати їхній неправомірній поведінці в подальшому та сприяти більш відповідальному ставленню до посадових обов' язків. У зв'язку із цим актуальним за сучасних умов $\epsilon$ аналіз складу дисциплінарного проступку «невиконання вимог щодо політичної неупередженості державного службовця» (п. 8 ч. 2 ст. 65 Закону), а також заходів дисциплінарної відповідальності, що передбачаються за його вчинення.

Аналіз останніх досліджень i публікацій. Учені в галузі адміністративного та трудового права традиційно приділяють значну увагу проблемі дисциплінарної відповідальності державних службовців. Це, наприклад, такі правники, як: Т.С. Аніщенко, Ю.П. Битяк, Л.Р. Біла-Тіунова, Н.М. Вапнярчук, С.В. Ківалов, Т.О. Коломоєць, В.К. Колпаков, Л.М. Корнута, О.Д. Новак, В.П. Тимощук та інші. Проте, незважаючи на детальний розгляд правових засад дисциплінарної відповідальності державних службовців, переліку їхніх дисциплінарних проступків, видів дисциплінарних стягнень, їхніх негативних наслідків тощо, у вітчизняній юриспруденції має місце незначна кількість наукових праць, присвячених дослідженню складів окремих дисциплінарних проступків державних службовців. Одним із таких складів дисциплінарних проступків і $\epsilon$ невиконання вимог щодо політичної неупередженості державного службовця.

Мета статті - відповідно до чинного законодавства України про державну службу схарактеризувати склад дисциплінарного проступку «невиконання вимог щодо політичної неупередженості державного службовця» (п. 8 ч. 2 ст. 65 Закону України «Про державну службу»), а також проаналізувати заходи дисциплінарної відповідальності, які застосовуються до державного службовця за його вчинення.

Виклад основного матеріалу. Дисциплінарна відповідальність державних службовців $\epsilon$ видом юридичної відповідальності, що полягає в накладенні дисциплінарних стягнень на державного службовця згідно із чинним законодавством [1, с. 37]. Отже, дисциплінарному проступку притаманна визначена єдність об' єктивних і суб'єктивних ознак, сукупність яких називається складом правопорушення [2, с. 63]. У юридичній науці склався класичний підхід стосовно чотирьохелементної конструкції правопорушення, обов'язкових і факультативних ознак. Саме склад правопорушення об'єднує найбільш типові й істотні 
характеристики проступку, є засадничим під час ухвалення рішення про накладення на державного службовця дисциплінарного стягнення чи закриття дисциплінарного провадження. Відповідно до усталених підходів розглянемо нижче невиконання вимог щодо політичної неупередженості як дисциплінарний проступок.

Розуміння об'єкта дисциплінарного проступку $\epsilon$ одним із найбільш спірних питань у проблемі дисциплінарної відповідальності державного службовця. Зокрема, ця дискусія пов'язується і з питанням галузевої належності інституту дисциплінарної відповідальності державних службовців. Представники науки трудового права висвітлюють такий загальний об'єкт, як суспільні відносини у сфері дотримання трудової дисципліни. У свою чергу, учені-адміністративісти наполягають, що дисциплінарна відповідальність державного службовця $\epsilon$ складовою частиною адміністративного права, комплексним інститутом права державної служби тощо [3, с. 202], який встановлює юридично-санкційні механізми для забезпечення службової дисципліни [4, с. 139].

Інститут дисциплінарної відповідальності державних службовців як складової частини адміністративного права у своїй праці влучно описує Л.М. Корнута. Вчена спирається на такі аргументи: 1) цей інститут реалізується у сфері функціонування органів державної влади, тобто пов'язаний із публічно-правовими суспільними відносинами; 2) цей інститут стосується особливого суб'єкта - державних службовців, тобто осіб, які заміщують державні посади в державних органах; реалізують державно-владні повноваження; забезпечують реалізацію державно-публічних завдань і функцій; 3) джерелами цього інституту $\epsilon$ здебільшого норми публічних галузей права, насамперед адміністративного права; 4) уперше законодавчо визначено фактичні підстави для застосування дисциплінарної відповідальності, яких не передбачено у Кодексі законів про працю (далі - КЗпП) України; 5) уперше законодавчо визначено систему дисциплінарних стягнень, зокрема й тих, що не передбачені у КЗпП України; 6) уперше законодавчо визначено порядок накладення дисциплінарних стягнень, який характеризується низкою особливостей [9, с. 203]. Через це розуміємо відповідальність за порушення трудової та службової дисципліни як нетотожні. Особливості дисциплінарної відповідальності за порушення службової дисципліни зумовлюють характерні риси загального та безпосереднього об'єкта.
Загальним об'єктом дисциплінарного проступку державного службовця треба вважати суспільні відносини, що складаються у сфері державної служби щодо забезпечення необхідного рівня службової дисципліни в державних органах [5, с. 66]. Безпосереднім об'єктом проступку можуть бути: а) службові обов'язки, визначені за посадою; б) правила додержання службової дисципліни (режим робочого часу, розпорядок дня, правила поводження зі службовими документами); в) загальні правила поведінки державних службовців поза службою, а також етичні вимоги, що висуваються до них [2, с. 64].

За п. 2 ч. 1 ст. 8 Закону основним обов'язком державного службовця реґламентується дотримання принципів державної служби. Конкретизуємо безпосередній об'єкт і ведемо мову про обов'язок додержання принципу політичної неупередженості (п. 8 ст. 4 Закону). У п. 8 ч. 1 ст. 4 Закону узагальнено згадується про дві основні вимоги: а) недопущення впливу політичних поглядів на діяльність державного службовця; б) утримання від їх демонстрації. У свою чергу, ст. 10 більш детально описує, які конкретні діяння вважатимуться такими, що порушують їх. Це, наприклад, неналежне виконання законних наказів / розпоряджень керівника внаслідок його партійної належності; участь у політичній агітації; неповідомлення в одноденний строк керівника державної служби про свою реєстрацію кандидатом у депутати тощо.

Зважаючи на особливості безпосереднього об'єкта, законодавець визначив п'ятнадцять окремих дисциплінарних проступків у ч. 2 ст. 65 Закону. Щодо цього привертає увагу колізія між п. 2 ч. 1 ст. 65 (порушення правил етичної поведінки державних службовців), яка, зокрема, відсилає до вимог Загальних правил етичної поведінки державних службовців та посадових осіб місцевого самоврядування, затверджених наказом Національного агентства України з питань державної служби (далі - НАДС) від 5 серпня 2016 р. № 158 (далі - Загальні правила) [7, с. 498], та п. 8 ч. 1 ст. 65 (порушення вимог щодо політичної неупередженості). Так, відповідно до пп. 2 п. III Загальних правил, державному службовцю заборонено будь-яким способом використовувати своє службове становище в політичних цілях, зокрема й для залучення державних службовців, посадових осіб місцевого самоврядування, працівників бюджетної сфери й інших осіб до участі в передвиборній агітації, акціях та заходах, що організовуються політичними пар- 
тіями. Цьому положенню кореспондують вимоги п. 4 та п. 5 ч. 3 ст. 10 Закону, згідно з якими державний службовець не має права «<... 4) залучати, використовуючи своє службове становище, державних службовців, посадових осіб місцевого самоврядування, працівників бюджетної сфери, інших осіб до участі у передвиборній агітації, акціях та заходах, що організовуються політичними партіями; 5) у будь-який інший спосіб використовувати своє службове становище в політичних цілях». Тому вчиненням наведених діянь державний службовець формально порушує і вимоги щодо політичної неупередженості, і правила етичної поведінки, а вони є різними дисциплінарними проступками. Така суперечність може негативним чином вплинути на кваліфікацію діяння державних службовців. Пропонуємо можливий шлях вирішення цієї колізії через застосування правила превалювання спеціальної норми (п. 8 ч. 2 ст. 65) над загальною (п. 2 ч. 2 ст. 65). Отже, використання державним службовцем у будь-який спосіб свого службового становища в політичних цілях, зокрема й для залучення державних службовців, посадових осіб місцевого самоврядування, працівників бюджетної сфери й інших осіб до участі в передвиборній агітації, акціях та заходах, що організовуються політичними партіями, має кваліфікуватися за п. 8 ч. 2 ст. 65 Закону.

Перейдемо до аналізу об'єктивної сторони дисциплінарного проступку. У теорії права наголошується, що об'єктивна сторона будь-якого дисциплінарного проступку складається із протиправної поведінки суб'єкта, шкідливих наслідків і причинного зв'язку між ними [8, с. 195]. Інакше кажучи, вона характеризує зовнішню сторону поведінки правопорушника й полягає в: (а) дії (бездіяльності) державного службовця; (б) наслідках, які настали; (в) причинному зв'язку між дією/бездіяльністю й результатом, який настав [9, с. 92]. Проте існує й альтернативна думка, за якою для кваліфікації дисциплінарного проступку спричинення негативних наслідків та наявність неминучого причинного зв'язку $\epsilon$ необов'язковими і можуть бути вибірковими для кожного конкретного проступку [8, с. 196].

3 огляду на ст. 10 Закону нами виокремлюються, зокрема, такі протиправні дії, як прояв порушення вимог політичної неупередженості: неналежне виконання законних наказів (розпоряджень), доручень керівників на підґрунті різних політичних поглядів; обіймання посади в керівних органах політичної партії; залучення, із використанням свого службового становища, до уча- сті в політичних агітаціях, акціях, заходах інших осіб; організація/участь державного службовця у страйку чи агітації тощо. Протиправна бездіяльність може виражатися, наприклад, у невиконанні законних наказів (розпоряджень), доручень керівників на підґрунті різних політичних поглядів; незупинення членства в політичній партії на час державної служби на посаді категорії «А»; неповідомлення керівника державної служби в одноденний строк про реєстрацію державного службовця кандидатом у депутати.

У контексті розгляду порушення вимог політичної неупередженості вважаємо, що цей вид проступку містить формальний склад. Тобто обов'язковою ознакою об'єктивної сторони цього проступку $\epsilon$ лише діяння. Відповідно й закінченим він уважатиметься з моменту безпосереднього вчинення дії/бездіяльності (або ухвалення рішення) на порушення обов'язків, передбачених ст. 10 Закону. Безсумнівно, недотримання вимог політичної неупередженості може вплинути негативним чином на ступінь довіри до державного органу, у якому порушник обіймає посаду державної служби тощо. Однак такі шкідливі наслідки виміряти якісно та кількісно об'єктивно неможливо для кваліфікації. Відповідно й називати їх закономірними і неминучими щодо діяння, як того вимагає теорія права, видається спірним.

Суб'єктом дисциплінарного проступку є державний службовець, тобто громадянин України, який обіймає посаду державної служби в органі державної влади, іншому державному органі, його апараті (у секретаріаті), одержує заробітну плату 3 державного бюджету та здійснює встановлені для цієї посади повноваження, безпосередньо пов'язані з виконанням завдань і функцій такого державного органу, а також дотримується принципів державної служби (ч. 2 ст. 1 Закону). Принагідно зауважимо, що за деякі порушення вимог політичної неупередженості суб'єкт має бути спеціальним - державним службовцем, який обіймає посаду державної служби виключно категорії «А». Це такі діяння: а) суміщення посади державної служби категорії «А» із членством у політичній партії (п. 1 ч. 3 ст. 10 Закону); б) суміщення посади державної служби категорії «А» зі статусом депутата місцевої ради (п. 3 ч. 3 ст. 10 Закону).

Щодо суб'єктивної сторони як внутрішньої характеристики проступку та психічного ставлення порушника до вчинюваного діяння відзначимо так. Законодавець під час визначення дисциплінарного проступку в ч. 1 ст. 65 згадує про обов'язкову ознаку суб'єктивної сторони - вину: «Підста- 
вою для притягнення державного службовця до дисциплінарної відповідальності є вчинення ним дисциплінарного проступку, тобто протиправної винної дії або бездіяльності чи прийняття рішення <...>. Водночас згадки про форму вини (умисел або необережність) визначення не містить. Уважаємо, що вина як ознака суб'єктивної сторони проступку може мати форму як умисної, так і необережної.

За загальним правилом, тлумачення форм вини відбувається через опис ставлення правопорушника як до діяння, так і до негативних наслідків. Але з огляду на не лише матеріальний, але й формальний склад деяких дисциплінарних проступків (зокрема, порушення вимог щодо політичної неупередженості), ми погоджуємося з тими вченими, які визначають умисел та необережність у правопорушеннях з формальним складом через ставлення суто до діяння. У такому разі дисциплінарне правопорушення варто вважати вчиненим умисно, якщо державний службовець, що його вчинив, усвідомлював протиправний характер свого діяння (дії чи бездіяльності), але, незважаючи на це, скоїв порушення. У свою чергу, дисциплінарне правопорушення варто вважати вчиненим з необережності, якщо державний службовець, що його скоїв, не усвідомлював протиправного характеру свого діяння, дії чи бездіяльності, хоча за даних конкретних умов повинен був і міг його усвідомлювати [7, с. 495].

Що стосується мотиву і мети проступку, то вони можуть бути різними. Проте щодо кваліфікації недотримання вимог політичної неупередженості державним службовцем мотив та мета як ознаки $\epsilon$ факультативними, а тому обов'язковому встановленню під час дисциплінарного провадження вони не підлягають.

Перейдемо до санкцій, які передбачаються за вчинення дисциплінарного проступку «невиконання вимог щодо політичної неупередженості державного службовця». У ч. 4 ст. 66 Закону закріплено, що в разі допущення державним службовцем дисциплінарного проступку, передбаченого п. 8 ч. 2 ст. 65 Закону, суб'єкт призначення або керівник державної служби може попередити такого державного службовця про неповну службову відповідність. 3 огляду на той факт, що ефективність дисциплінарного стягнення залежить від обсягу обмежень, яких має зазнати порушник за своє діяння, зупинимось на цьому питанні.

Нами виокремлюються три основні негативні наслідки, яких має зазнати державний службовець протягом року після накладення стягнення у вигляді повідомлення про неповну службову відповідність: а) державному службовцю не присвоюється черговий ранг (ч. 6 ст. 39); б) не здійснюється просування державного службовця по службі (ч. 2 ст. 40); в) до державного службовця не застосовуються заохочення (ч. 3 ст. 53). Відзначимо, що ці наслідки є такими ж і для іншого різновиду дисциплінарного стягнення - догани. Щодо зауваження, то відмінність лише в тому, що до дисциплінарного службовця можуть застосовуватися заходи заохочення протягом строку дії наведеного стягнення (ч. 3 ст. 79). На наш погляд, практична різниця в негативних наслідках цих трьох дисциплінарних санкцій незначна. Водночас прийнято вважати, що неповна службова відповідність $є$ дещо суворішим видом дисциплінарного стягнення, ніж догана, але значно м'якшим порівняно зі звільненням із посади державної служби [7, с. 531].

Підкреслимо, що Законом України «Про державну службу» не передбачається винятковий вид дисциплінарного стягнення - звільнення, навіть за повторне протягом року невиконання державним службовцем вимог щодо політичної неупередженості. Більш шкідливим, на думку законодавця, $\epsilon$ повторний протягом року прогул державного службовця без поважних причин. Лише за систематичне вчинення цього різновиду дисциплінарного проступку в ч. 5 ст. 66 Закону передбачається звільнення з посади державної служби.

На наш погляд, зважаючи на базове значення політичної неупередженості для реформування вітчизняної державної служби й адаптації до європейських стандартів, варто констатувати, що чинним законодавством України реґламентовано досить м'яку санкцію за дисциплінарний проступок «невиконання вимог щодо політичної неупередженості державного службовця». Ризик використання свого службового становища в політичних цілях переважно стосується державних службовців саме зі значним обсягом повноважень, що мають безпосередній доступ до залучення потужного адміністративного ресурсу (як класичний приклад можна навести примусове зобов'язання працівників бюджетної сфери до участі в мітингах, демонстраціях на підтримку тієї чи іншої політичної партіі). Такі державні службовці вже мають досиьть високий ранг, обіймають посаду категорії «Б» або навіть «A», i тому негативні наслідки у вигляді неприсвоєння чергового рангу, непросування по службі або ж незастосування заохочень не буде ефективним засобом превенції порушень. 
Заслуговує на увагу досвід європейських держав. За приклад наведемо п. 1 ч. 4 ст. 29 Закону Литовської Республіки «Про публічну службу» від 23 квітня 2002 р., згідно з яким звільнення зі служби як дисциплінарна санкція може бути накладена за діяльність, несумісну з публічною службою [10, с. 441]. Уважаємо, що неправомірну політичну активність державних службовців (обіймання посади в керівних органах політичної партії, членство в політичній партії або суміщення служби зі статусом депутата місцевої ради посадовцями категорії «А») можна розглядати як діяльність, несумісну з публічною, професійною, політично неупередженою державною службою. Також примітною $\epsilon$ не тільки ч. 4, але й ч. 5 ст. 29 Закону Литовської Республіки: (а) за ч. 4 ст. 29 передбачається перелік дисциплінарних проступків, за вчинення яких настає звільнення; (б) відповідно до ч. 5 ст. 29, за повторне (протягом року після винесення державному службовцю суворої догани як дисциплінарної санкції) учинення всіх інших дисциплінарних проступків застосовується звільнення зі служби [10, с. 441].

Зважаючи на закордонний досвід, а також важливість принципу політичної неупередженості для державної служби в Україні, на нашу думку, доцільно внести зміни до ч. 5 ст. 66 Закону «Про державну службу» від 10 грудня 2015 р. та передбачити застосування звільнення з посад державної служби за повторне протягом року вчинення такого дисциплінарного проступку, як невиконання вимог щодо політичної неупередженості державного службовця.

Висновки. Проведений аналіз дає нам змогу зробити такі висновки. Політична неупередженість $\epsilon$ важливим принципом державної служби, який наближає вітчизняну державну службу до європейський стандартів. У зв'язку із цим вагома роль відводиться засобам забезпечення реалізації цього принципу, зокрема й дисциплінарній відповідальності державних службовців. Склад дисциплінарного проступку «невиконання вимог щодо політичної неупередженості державного службовця» (п. 8 ч. 2 ст. 65 Закону) характеризується такими елементами, як: а) безпосередній об'єкт як обов'язок додержуватись принципу політичної неупередженості; б) об'єктивна сторона аналізованого проступку характеризується виключно діянням як обов'язковою ознакою. Наслідки і причинний зв'язок виступають факультативними ознаками; в) загальним суб' $є$ ктом проступку $\epsilon$ державний службовець, який обіймає посаду державної служби незалежно

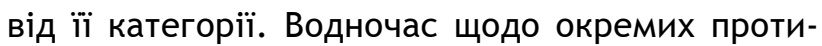
правних діянь як порушення вимог політичної неупередженості можна виділяти спеціального суб'єкта - державних службовців, які обіймають посаду державної служби категорії «А» (вищий корпус державної служби»); г) суб'єктивна сторона характеризується виною як обов'язковою ознакою (умисел та необережність). Мотив і мета $\epsilon$ факультативними ознаками суб'єктивної сторони.

Важливим напрямом подальшої розбудови державної служби в Україні як політично неупередженого інституту має стати посилення дисциплінарної відповідальності за вчинення такого дисциплінарного проступку, як «невиконання вимог щодо політичної неупередженості державного службовця». Зокрема, доцільно передбачити застосування звільнення з посад державної служби до тих державних службовців, які були повідомлені про неповну службову відповідність за «невиконання вимог щодо політичної неупередженості державного службовця» та вчинили цей проступок протягом року повторно.

\section{Література}

1. Вапнярчук Н.M. Теоретико-прикладні проблеми правового регулювання дисциплінарної відповідальності державних службовців в Україні : монографія. Харків : Юрайт, 2012. 312 с.

2. Дисциплінарно-деліктне право України : навчальний посібник / за заг. ред. Т.О. Коломоєць, В.К. Колпакова. Київ : Ін Юре, 2016. 464 с.

3. Миронюк Р.В. Новітні підходи до встановлення дисциплінарної відповідальності в публічній службі. Науковий вісник Дніпропетровського державного університету внутрішніх справ. 2015. № 1. C. 200-207.

4. Янюк Н.В. Дисциплінарна відповідальність державних службовців за Законом України «Про державну службу» (2015) : правовий аналіз. Вісник Львівського університету. Серія «Юридична». 2016. № 62. С. 138-147.

5. Новак О.Д. Правові засади дисциплінарної відповідальності державних службовців в Україні : монографія / за заг. ред. В.В. Зуй. Харків : Право, 2015. $200 \mathrm{c}$.

6. Панова Н.С. Політична неупередженість державного службовця як гарантія ефективності та стабільності державної служби. Науковий вісник Ужгородського національного університету. Серія «Право». 2017. № 47. С. 144-147.

7. Науково-практичний коментар до Закону України «Про державну службу» / ред. кол. : 
Протидія злочинності: проблеми практики та науково-методичне забезпечення

В.А. Дерець (відп. ред.) та ін. Київ : ФОП Москаленко O.M., 2017. 796 c.

8. Андрєєв В.О. Відповідальність за порушення присяги державного службовця. Ефективність державного управління. 2018. № 1. С. 192-199.

9. Ківалов С.В., Біла-Тіунова Л.Р., Корнута Л.М. Дисциплінарна відповідальність державного службовця в Україні: питання теорії і правового регулювання : монографія. Одеса : Фенікс, 2013. 274 с.
10. Публічна служба. Зарубіжний досвід та пропозиції для України / за заг. ред. В.П. Тимощука, А.М. Школика. Київ : Конус-Ю, 2007. 735 с.

Андрєєва А. П., студентка IV курсу господарсько-правового факультету Національного юридичного університету імені Ярослава Мудрого 